\title{
Role of Hydrogen Peroxide in Neutrophil-mediated Destruction of Cultured Endothelial Cells
}

\author{
Stephen J. Weiss, Judy Young, Albert F. Lobuglio, Adam Slivka, \\ and NADim F. NimeH, Simpson Memorial Institute, University of Michigan, \\ Ann Arbor, Michigan 48109
}

\begin{abstract}
A B S T R A C T Human neutrophils stimulated with phorbol myristate acetate were able to destroy suspensions or monolayers of cultured human endothelial cells. Neutrophil-mediated cytotoxicity was related to phorbol myristate acetate concentration, time of incubation and neutrophil number. Cytolysis was prevented by the addition of catalase, while superoxide dismutase had no effect on cytotoxicity. The addition of the heme-enzyme inhibitors, azide or cyanide, markedly stimulated neutrophil-mediated damage while exogenous myeloperoxidase failed to stimulate cytolysis. Neutrophils isolated from patients with chronic granulomatous disease did not destroy the endothelial cell targets while myeloperoxidase-deficient neutrophils successfully mediated cytotoxicity. Endothelial cell damage mediated by the myeloperoxidase deficient cells was also inhibited by catalase but not superoxide dismutase. The addition of purified myeloperoxidase to the deficient cells did not stimulate cytotoxicity. Glucose-glucose oxidase, an enzyme system capable of generating hydrogen peroxide, could replace the neutrophil as the cytotoxic mediator. The addition of myeloperoxidase at low concentrations of glucose oxidase did not increase cytolysis, but at the higher concentrations of glucose oxidase it stimulated cytotoxicity. The destruction of endothelial cells by the glucose oxidase-myeloperoxidase system was inhibited by the addition of hypochlorous acid scavengers. In contrast, neutrophil-mediated cytolysis was not effectively inhibited by the hypochlorous acid scavengers. Based on these observations, we propose that human neutrophils can destroy cultured human endothelial cells by generating cytotoxic quantities of hydrogen peroxide.
\end{abstract}

\section{INTRODUCTION}

Intact endothelial cell metabolism and functional activity plays an integral role in maintaining vascular

Received for publication 2 January 1981 and in revised form 3 May 1981. integrity (1-3). Injury of the endothelium appears to be an important step in the pathogenesis of immune or infection mediated vasculitides and atherosclerosis (1-3). The human neutrophil possesses a powerful cytotoxic armamentarium $(4,5)$ and its intravascular activation could lead to endothelial cell injury and death.

Neutrophils ingesting particles, adhering to immune coated surfaces, or responding to soluble stimuli undergo a burst in metabolic activity, discharge lysosomal components, and generate reactive oxygen metabolites $(4,5)$. In order to examine the destructive potential of the intact leukocyte, we have used a model system in which human neutrophils are exposed to the soluble stimulant, phorbol myristate acetate (PMA), ${ }^{1}$ and incubated with a target cell population (6-9). In earlier studies, this model system has allowed us to demonstrate two distinct mechanisms of neutrophilmediated cytotoxicity (6-9). Erythrocyte targets were lysed by a reaction between superoxide anion $\left(\mathrm{O}_{2}{ }^{-}\right)$ and oxy-hemoglobin, whereas tumor cells were destroyed by an oxidant generated from the hydrogen peroxide $\left(\mathrm{H}_{2} \mathrm{O}_{2}\right)$-myeloperoxidase-halide system $(8,9)$. In this study we have examined the ability of PMAstimulated neutrophils to damage cultured human endothelial cells and have identified $\mathrm{H}_{2} \mathrm{O}_{2}$ as the cytotoxic mediator.

\section{METHODS}

Neutrophil preparation. Human neutrophils were obtained from heparinized venous blood of normal volunteers or patients with chronic granulomatous disease or myeloperoxidase deficiency. Patients with chronic granulomatous disease were identified by Dr. J. Silva (University Hospital, Ann Arbor, Mich.). An adult with myeloperoxidase deficiency was identified and blood generously provided by R. K. Root (Yale-New Haven Hospital, New Haven,

${ }^{1}$ Abbreviations used in this paper: CEM, human T lymphoblast; EBSS, Earle's balanced salt solution; PMA, phorbol myristate acetate. 
Conn.). Leukocytes were isolated by Ficoll-Hypaque density centrifugation and dextran sedimentation as previously described (10). Neutrophils were suspended in Earle's balanced salt solution (EBSS; Gibco Laboratories, Grand Island Biological Co., Grand Island, N. Y.) for all further studies.

Target cell preparations. Endothelial cells were obtained from human umbilical cords by the method of Gimbrone (11). The cells were suspended in Medium 199 with $25 \mathrm{mM}$ Hepes buffer (Gibco Laboratories) and $20 \%$ fetal calf serum. The endothelial cells were seeded in $25 \mathrm{~cm}^{2}$ tissue culture flasks (Corning Glass Works, Corning, N. Y.) or Falcon multiwell tissue culture plates $\left(2.2 \mathrm{~cm}^{2}\right.$, Falcon Labware, Becton, Dickinson \& Co., Oxnard, Calif.). The cells reached confluency after $3-5 \mathrm{~d}$ and were used for the cytotoxicity assays. Endothelial cells were identified by phase-contrast morphology (11), the presence of WeibelPalade bodies (12) in electron micrographs and by Factor VIII antigen (13).

Endothelial cell monolayers in the $25-\mathrm{cm}^{2}$ flasks $\left(\cong 2 \times 10^{6}\right.$ cells) were radioactively labeled with $75 \mu \mathrm{Ci}$ of $\mathrm{Na}_{2}{ }^{51} \mathrm{CrO}_{4}$ $\left({ }^{51} \mathrm{Cr}\right.$, New England Nuclear, Boston, Mass.) in $5 \mathrm{ml}$ of culture medium for $90 \mathrm{~min}$ at $37^{\circ} \mathrm{C}$. The monolayer was then washed three times with $\mathrm{Ca}^{++}$and $\mathrm{Mg}^{++}$free Hanks' balanced salt solution (Gibco Laboratories). The labeled cells were removed from the plates by a 10 -min incubation with $0.1 \%$ collagenase (Type I, $140 \mathrm{U} / \mathrm{mg}$, Worthington Biochemical Co., Freehold, N. J.) and $0.01 \%$ EDTA in $\mathrm{Ca}^{++}$. and $\mathrm{Mg}^{++}$-free Hanks' balanced salt solution at $37^{\circ} \mathrm{C}(11)$. Cells were washed twice $\left(200 \mathrm{~g}\right.$ for $10 \mathrm{~min}$ at $\left.4^{\circ} \mathrm{C}\right)$, resuspended in EBSS, and counted on a hemacytometer. Cells were always $>90 \%$ viable by trypan blue exclusion. When experiments were performed with intact endothelial cell monolayers, the cells were treated in an identical manner except $15 \mu \mathrm{Ci}$ of ${ }^{51} \mathrm{Cr}$ were added to the wells $\left(\cong 1.8 \times 10^{5}\right.$ cells) in a final volume of $1 \mathrm{ml}$.

Human T-lymphoblasts (CEM) were radioactively labeled by incubating $10^{7}$ cells with $100 \mu \mathrm{Ci}$ of ${ }^{51} \mathrm{Cr}$ at $37^{\circ} \mathrm{C}$ as previously described (8). This $\mathrm{T}$ cell line lacks demonstrable Epstein-Barr virus genome and possesses the human histocompatibility leukocyte (HLA) antigen phenotype Al, A10, B8, and BW40 (14).

Cytotoxicity assay. The cytotoxicity assay was performed with endothelial cell suspensions, endothelial cell monolayers or CEM. In experiments with endothelial cell suspensions or CEM, $2 \times 10^{4}{ }^{51} \mathrm{Cr}$-labeled target cells were incubated with neutrophils or glucose oxidase (Type IV, 1,400 U/ml; Sigma Chemical Co.) in EBSS supplemented with $0.25 \%$ fetal calf serum. Assays were done in duplicate in Costar microtest plates (Bellco Glass, Inc., Vineland, N. J.) and the final volume of the reaction mixture was $0.3 \mathrm{ml}$. In the neutrophil studies, incubations were initiated by the addition of PMA (Consolidated Midland Corp., Brewster, N. Y.). PMA stock solutions ( $1 \mathrm{mg} / \mathrm{ml})$ were stored in dimethylsulfoxide at $-70^{\circ} \mathrm{C}$. In the glucose oxidase studies, the addition of the enzyme marked the start of the incubation period. Immediately after the addition of PMA or glucose oxidase, the samples were centrifuged at $50 \mathrm{~g}$ for $3 \mathrm{~min}$ at $25^{\circ} \mathrm{C}$. The samples were then placed in a humidified atmosphere of $95 \%$ air $/ 5 \% \quad \mathrm{CO}_{2}$ at $37^{\circ} \mathrm{C}$. Experiments with ${ }^{51} \mathrm{Cr}$-labeled endothelial cell monolayers were performed in an identical manner except the cell number was $\cong 1.8 \times 10^{5}$ and the final reaction volume was $1.5 \mathrm{ml}$.

Other additions to the cytotoxicity systems included bovine superoxide dismutase $(3,000 \mathrm{U} / \mathrm{mg}$, Sigma Chemical Co.), bovine catalase $(120,000 \mathrm{U} / \mathrm{mg}$, Worthington Biochemical), azide, cyanide, mannitol (Fischer Scientific
Co., Fairlawn, N. J.), or L-amino acids (Sigma Chemical Co.). Purified canine myeloperoxidase was prepared (15) and provided by Dr. J. Schultz (Papanicolaou Cancer Research Inst., Miami, Fla.). The enzyme was assayed by the orthodianisidine method (16). Catalase was washed over an XM100 ultrafiltration membrane (Amicon Corp., Lexington, Mass.) before use.

After various incubation periods the samples were centrifuged $(100 \mathrm{~g}, 5 \mathrm{~min})$ and one-third of the supernate removed to determine ${ }^{51} \mathrm{Cr}$ release. Cytotoxicity was expressed as the percentage of ${ }^{51} \mathrm{Cr}$ release calculated by the formula:

$$
\text { percent cytotoxicity }=\frac{(A-B)}{(C-B)} \times 100,
$$

where $A$ is the mean counts per minute in the supernate of samples containing PMA-stimulated neutrophils or glucose oxidase and target cells, $B$ is the mean counts per minute in the supernate of samples containing target cells alone, and $\mathrm{C}$ is the mean counts per minute of target cells added to each sample.

In selected experiments performed with endothelial cell monolayers, cytolysis was determined both by ${ }^{51} \mathrm{Cr}$ release and direct cell counts. At the end of the incubation period, a portion of the supernate was removed for ${ }^{51} \mathrm{Cr}$ release and the endothelial cells removed by treatment with $0.1 \%$ collagenase and $0.01 \%$ EDTA for $10 \mathrm{~min}$ at $37^{\circ} \mathrm{C}$. The endothelial cells were then counted on a hemacytometer by light and phase-contrast microscopy.

$\mathrm{H}_{2} \mathrm{O}_{2}$ assay. The quantitation of $\mathrm{H}_{2} \mathrm{O}_{2}$ generated by neutrophils or glucose oxidase was determined by the method of Thurman et al. (17). Glucose oxidase or PMA-stimulated neutrophils $\left(0.5-2.0 \times 10^{5}\right)$ were incubated with $1 \mathrm{mM}$ azide in a final volume of $1 \mathrm{ml}$ in EBSS. At various times the reaction was terminated by the addition of $0.1 \mathrm{ml}$ trichloroacetic acid $(50 \%$ wt/vol). The samples were centrifuged $(500 \mathrm{~g}, 10 \mathrm{~min})$ and $0.2 \mathrm{ml}$ of $10 \mathrm{mM}$ ferrous ammonium sulfate and $0.1 \mathrm{ml}$ of $2.5 \mathrm{M}$ potassium thiocyanate (both from Fisher Scientific Co.) added to the supernate. The adsorption of the ferrithiocyanate complex was measured at 480 $\mathrm{nm}$ and compared to a standard curve generated from dilutions of concentration $\mathrm{H}_{2} \mathrm{O}_{2}$. The $\mathrm{H}_{2} \mathrm{O}_{2}$ concentration was calculated from the absorbance at $230 \mathrm{~nm}$ assuming an extinction coefficient of $81 \mathrm{M}^{-1} \mathrm{~cm}^{-1}(18)$.

\section{RESULTS}

Neutrophil-mediated endothelial cell destruction. As summarized in Table I, PMA-stimulated neutrophils were capable of destroying either suspensions or monolayers of human endothelial cells. Neither PMA nor neutrophils alone mediated significant cytotoxicity. Maximal cytolysis was obtained with a PMA dose of $10 \mathrm{ng} / \mathrm{ml}$ (data not shown). Fig. 1 illustrates the relationship of neutrophil number to endothelial cell destruction. Significant ${ }^{51} \mathrm{Cr}$ release was seen with as few as 25,000 neutrophils, i.e., an effector to target cell ratio of $1.25: 1$. The time-course of ${ }^{51} \mathrm{Cr}$ release is shown in Fig. 2 with maximal release occurring between 4 and $6 \mathrm{~h}$. Cytotoxicity was also determined with endothelial cell monolayers by direct hemacytometer counts of the cells remaining after a 6 -h incubation. These results did not differ from those obtained 
TABLE I

Endothelial Cell Destruction by PMA-stimulated Neutrophils

\begin{tabular}{lcc}
\hline \multirow{2}{*}{ Additive } & \multicolumn{2}{c}{ Percent cytotoxicity* } \\
\cline { 2 - 3 } \multicolumn{1}{c}{} & Suspensions & Monolayer \\
\hline PMA $\$$ & $0.3 \pm 0.4$ & $0.1 \pm 0.2$ \\
Neutrophils $\S$ & $2.1 \pm 1.4$ & $1.0 \pm 1.1$ \\
Neutrophils + PMA & $44.2 \pm 10.9$ & $43.6 \pm 13.0$ \\
\hline
\end{tabular}

* Expressed as mean percent cytotoxicity $\pm 1 \mathrm{SD}$ of $2 \times 10^{4}$ endothelial cells in suspension $(n=20)$ or $1.8 \times 10^{5}$ endoethelial cells in monolayer $(n=5)$ in $6 \mathrm{~h}$. The spontaneous release of ${ }^{51} \mathrm{Cr}$ at $6 \mathrm{~h}$ was $17.1 \pm 5.2$ and $15.0 \pm 4.5$ for the suspension and monolayer experiments, respectively. The final serum concentration was $0.25 \%$.

‡ Phorbol myristate acetate $10 \mathrm{ng} / \mathrm{ml}$.

$\$$ Neutrophil number was $2 \times 10^{5}$ with target cell suspensions and $1.8 \times 10^{6}$ with the endothelial cell monolayers.

with ${ }^{51} \mathrm{Cr}$ release. Fetal calf serum did not inhibit endothelial cell cytotoxicity unless concentration of $>10 \%$ were used. Experiments were routinely performed with a final serum concentration of $0.25 \%$ and a 6-h incubation period.

Role of $\mathrm{H}_{2} \mathrm{O}_{2}$ in neutrophil-mediated endothelial cell cytotoxicity. We have previously demonstrated that PMA-stimulated neutrophils can destroy target cells by generating superoxide anion $\left(\mathrm{O}_{2}^{--}\right), \mathrm{H}_{2} \mathrm{O}_{2}$ and releasing myeloperoxidase (6-9). In order to characterize the possible role of $\mathrm{O}_{2}{ }^{-}$or $\mathrm{H}_{2} \mathrm{O}_{2}$ in the cytotoxic event, experiments were performed in the presence of superoxide dismutase or catalase. Superoxide dismutase lowers the $\mathrm{O}_{2}{ }^{-}$- concentration, whereas catalase degrades $\mathrm{H}_{2} \mathrm{O}_{2}$. As shown in Fig. 3, superoxide dismutase had no inhibitory effect while catalase almost completely prevented cytotoxicity. Heat-inactivated calalase failed to inhibit endothelial cell cytolysis ( $94 \pm 5 \%$ of control cytotoxicity, $n=4$ ). The addition of catalase to the assay system $60 \mathrm{~min}$ after the start of the incubation had no inhibitory effect on cytolysis. Thus, $\mathrm{H}_{2} \mathrm{O}_{2}$ appears to play a key role in this cytotoxic event during the 1 st $h$ of incubation.

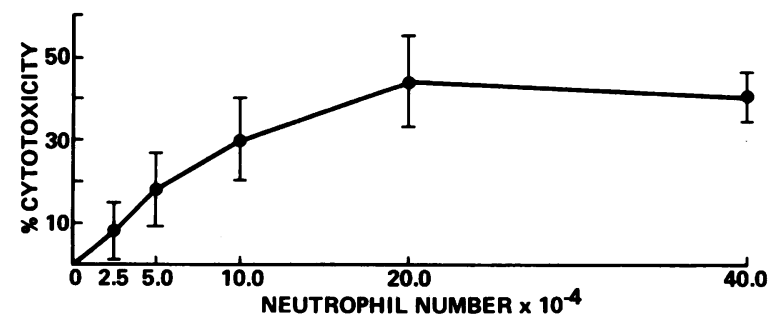

FiguRE 1 Effect of neutrophil number on the cytolysis of $2 \times 10^{4}$ endothelial cells in suspension at a PMA concentration of $10 \mathrm{ng} / \mathrm{ml}$ over a 6-h period of incubation. Results are expressed as the mean percent of cytotoxicity \pm 1 SD of four experiments.

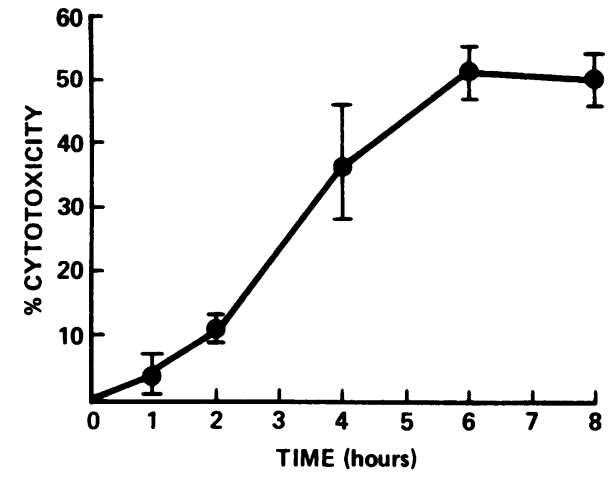

FigURE 2 The release of ${ }^{51} \mathrm{Cr}$ from a suspension of $2 \times 10^{4}$ endothelial cells incubated with $2 \times 10^{5}$ neutrophils and 10 $\mathrm{ng} / \mathrm{ml}$ of PMA over an 8-h period of incubation. The spontaneous release from the endothelial cells at $8 \mathrm{~h}$ was $21 \pm 2 \%$. Results are expressed as the mean percentage of cytotoxicity \pm 1 SD of three experiments.

$\mathrm{H}_{2} \mathrm{O}_{2}$ and chloride are capable of interacting with the lysosomal enzyme myeloperoxidase to form a powerful cytotoxic system $(4,5)$. To determine the possible role of this enzyme in neutrophil-mediated cytotoxicity, experiments were performed in the presence of the heme-enzyme inhibitors azide or cyanide. As shown in Fig. 3, both of these agents markedly stimulated cytotoxicity. Neither of the inhibitors alone had any effect on ${ }^{51} \mathrm{Cr}$ release. Although PMA has been reported to be a weak stimulus for the release

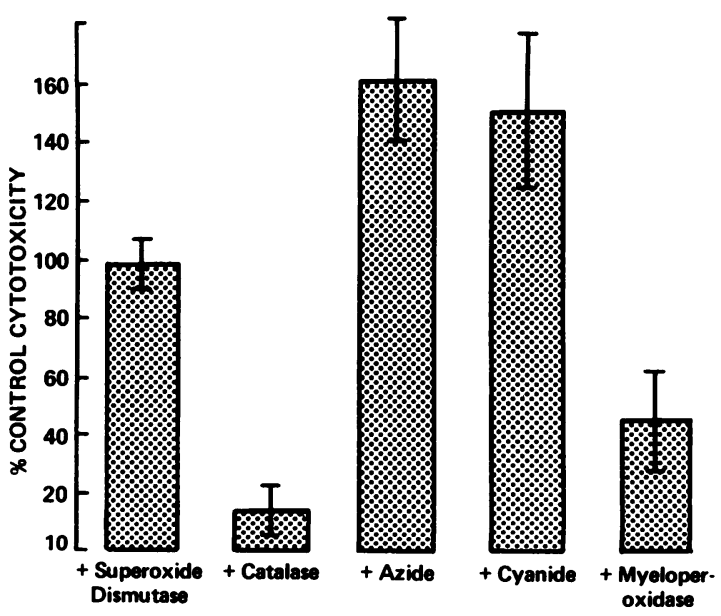

FIGURE 3 The effect of superoxide dismutase $(15 \mu \mathrm{g} / \mathrm{ml})$, catalase $(10 \mu \mathrm{g} / \mathrm{ml})$, azide $(1 \mathrm{mM})$, cyanide $(1 \mathrm{mM})$ and myeloperoxidase $(16 \mathrm{mU})$ on the cytolysis of $2 \times 10^{4}$ endothelial cells by $2 \times 10^{5}$ neutrophils stimulated with $10 \mathrm{ng} / \mathrm{ml}$ of PMA over a 6-h incubation. All of the enzymes and inhibitors were incubated with the effector and target cells for $5 \mathrm{~min}$ before the addition of PMA. None of the agents alone stimulated ${ }^{51} \mathrm{Cr}$ release above background. Results are expressed as the mean percentage of control cytotoxicity \pm 1 SD of eight experiments. 
of myeloperoxidase $(19,20)$, the addition of exogenous myeloperoxidase failed to stimulate cytotoxicity (Fig. 3).

$\mathrm{H}_{2} \mathrm{O}_{2}$ is also capable of reacting with a variety of metal complexes to form the extremely reactive hydroxyl radical $\left(\mathrm{OH}^{*}\right)(21)$. The addition of high concentrations of $\mathrm{OH}$ scavengers $(20 \mathrm{mM}$ ethanol or mannitol) failed to inhibit neutrophil-mediated cytotoxicity $(89 \pm 5 \%$ and $92 \pm 4 \%$ of control, respectively, $n=3)$. Thus, no role could be demonstrated for this species under the conditions used.

Further characterization of the mechanism of cytotoxicity was determined with neutrophils isolated from patients with chronic granulomatous disease or hereditary myeloperoxidase deficiency. Chronic granulomatous disease neutrophils discharge lysosomal components, but are incapable of generating oxygen metabolites while myeloperoxidase-deficient cells can generate oxygen metabolites but lack myeloperoxidase $(4,5)$. The chronic granulomatous disease neutrophils were incapable of mediating cytotoxicity, whereas myeloperoxidase-deficient cells successfully destroyed the endothelial cell targets (Fig. 4). Experiments designed to determine the mechanism of cytotoxicity utilized by the myeloperoxidase deficient cells are shown in Fig. 5. Although superoxide dismutase had no inhibitory effect, catalase effectively inhibited cytolysis. The addition of azide enhanced cytotoxicity while exogenous myeloperoxidase failed to stimulate cytolysis (Fig. 5). In addition, $\mathrm{OH}^{\prime}$ scavengers were ineffective in preventing endothelial cell destruction (data not shown). Thus, it appears that both normal and myeloperoxidase deficient cells can destroy

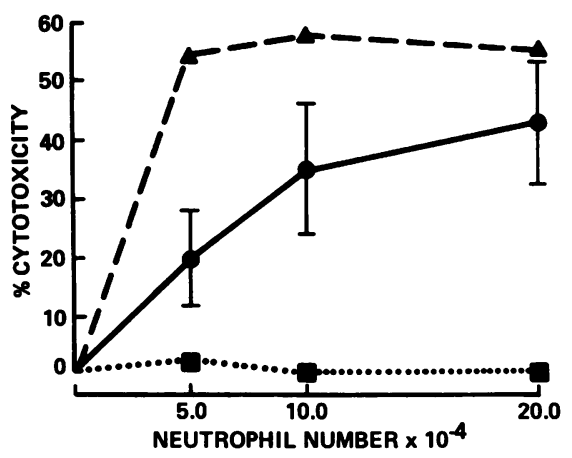

FIGURE 4 The effect of varying numbers of neutrophils isolated from normals (O), patients with chronic granulomatous disease $(\square)$ or a patient with myeloperoxidase deficiency $(\Delta)$ on the destruction of $2 \times 10^{4}$ endothelial cells with a PMA concentration of $10 \mathrm{ng} / \mathrm{ml}$ and a 6-h incubation. Experiments with chronic granulomatous disease cells and myeloperoxidase deficient cells are expressed as the mean of two experiments performed with two patients and the results of two experiments with one patient, respectively. Cytolysis mediated by the normal neutrophils is expressed as the mean percent of cytotoxicity $\pm 1 \mathrm{SD}$ of four experiments performed in tandem with the patient cells.

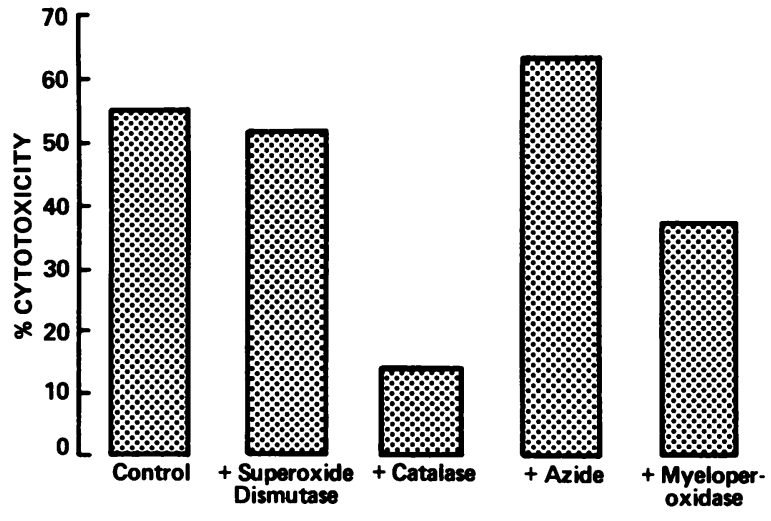

Figure 5 Effect of superoxide dismutase (15 $\mu \mathrm{g} / \mathrm{ml})$, catalase $(10 \mu \mathrm{g} / \mathrm{ml})$, azide $(1 \mathrm{mM})$, and myeloperoxidase (16 $\mathrm{mU}$ ) on the destruction of $2 \times 10^{4}$ endothelial cells by $2 \times 10^{5}$ myeloperoxidase deficient neutrophils with a PMA concentration of $10 \mathrm{ng} / \mathrm{ml}$ over a 6-h incubation. Results are expressed as the mean of two experiments with a single patient.

endothelial cell targets by a mechanism dependent on $\mathrm{H}_{2} \mathrm{O}_{2}$.

Glucose-glucose oxidase-mediated endothelial cell destruction. In order to test the cytotoxic potential of $\mathrm{H}_{2} \mathrm{O}_{2}$ alone, a cell-free model system was used. Glucose oxidase divalently reduced $\mathrm{O}_{2}$ directly to $\mathrm{H}_{2} \mathrm{O}_{2}$ at a slow continuous rate and was tested for its ability to mediate cytotoxicity. Fig. 6 illustrates the sensitivity of a suspension of endothelial cells to the glucose oxidase system. Cytotoxicity could be demonstrated with as little as $0.66 \mathrm{mU}$ of enzyme. When 1.32 $\mathrm{mU}$ of glucose oxidase was added, it mediated $65 \%$ cytotoxicity while generating $12 \pm 5 \mathrm{nmol}$ of $\mathrm{H}_{2} \mathrm{O}_{2}$ $(n=4)$. This compares to the ability of $2 \times 10^{5}$ PMA-

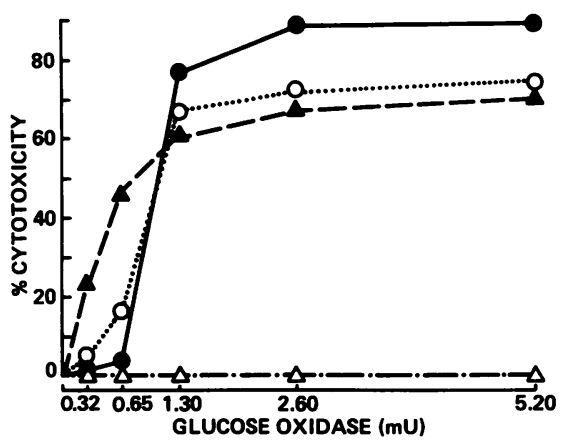

FIGURE 6 Effect of varying concentrations of glucose oxidase in the absence or presence of myeloperoxidase on the destruction of $2 \times 10^{4}$ endothelial cells or CEM. Reaction mixtures of target cells and enzymes were coincubated in EBSS supplemented with $0.25 \%$ fetal calf sera for $6 \mathrm{~h}$ at $37^{\circ} \mathrm{C}$ in an atmosphere of $5 \% \mathrm{CO}_{2} / 95 \%$ air. (a) endothelial cells $(O),(b)$ endothelial cells and $16 \mathrm{mU}$ myeloperoxidase (O), (c) $\operatorname{CEM}(\triangle)$, and $(d) \mathrm{CEM}$ and $16 \mathrm{mU}$ myeloperoxidase $(\Delta)$. Results are expressed as the mean of three experiments. 
stimulated neutrophils to produce $20 \pm 5 \mathrm{nmol}$ of $\mathrm{H}_{2} \mathrm{O}_{2}$ $(n=4)$. Endothelial cell destruction was effectively prevented by exogenous catalase $(10 \mu \mathrm{g} / \mathrm{ml})$ and was not stimulated by the addition of $1 \mathrm{mM}$ azide. Identical results were obtained with endothelial cell monolayers exposed to the glucose oxidase system. In contrast, CEM targets were insensitive to $\mathrm{H}_{2} \mathrm{O}_{2}$ since none of the doses of glucose oxidase used produced cytolysis (Fig. 6).

Role of the myeloperoxidase system in endothelial cell destruction. Thus far, we have demonstrated the myeloperoxidase-deficient neutrophils or normal neutrophils incubated with heme enzyme inhibitors are capable of destroying endothelial cells. Although these results demonstrate that $\mathrm{H}_{2} \mathrm{O}_{2}$ can mediate endothelial cell cytolysis, these data do not rule out an additional role for the myeloperoxidase system in the normal neutrophils. To explore the sensitivity of endothelial cells to myeloperoxidase-dependent cytolysis, myeloperoxidase was added to the glucose oxidase system. At high doses of glucose oxidase, myeloperoxidase enhanced endothelial cell lysis but at the lower doses of glucose oxidase the addition of myeloperoxidase did not stimulate cytotoxicity (Fig. 6). These results contrast with those obtained with the CEM targets where cytolysis was totally dependent on the addition of myeloperoxidase (Fig. 6).

The $\mathrm{H}_{2} \mathrm{O}_{2}$-myeloperoxidase- $\mathrm{Cl}^{-}$system is capable of generating the powerful oxidant hypochlorous acid ( $\mathrm{HOCl})(22-24) . \mathrm{HOCl}$ is known to react rapidly with amines, amides, or sulfhydryl groups and can destroy a variety of biological targets including bacteria and tumor cells $(5,8,25,26)$. If $\mathrm{HOCl}$ plays a role in endothelial cell cytotoxicity, then compounds known to scavenge the species should protect the cell from damage $(8,25,26)$. When serine, valine, or isoleucine $(20 \mathrm{mM})$, compounds known to react rapidly with $\mathrm{HOCl}$, were added to a glucose oxidase $(2.6 \mathrm{mU})$ myeloperoxidase $(16 \mathrm{mU})$ system endothelial cell cytotoxicity was reduced to zero percent $(n=4)$. The addition of these amino acids to the glucose oxidase system did not inhibit cytotoxicity $(n=4)$. Thus, while $\mathrm{H}_{2} \mathrm{O}_{2}$ dependent destruction is not affected by the amino acids, myeloperoxidase-mediated damage can be prevented by these compounds.

In order to investigate the potential role of the myeloperoxidase system in neutrophil-mediated endothelial cell destruction, experiments were performed in the presence of these $\mathrm{HOCl}$ scavengers. In eight experiments, amino acids that were capable of completely protecting endothelial cells from myeloperoxidase-dependent damage produced modest inhibition of neutrophil-mediated cytolysis (Table II). In contrast, neutrophil-mediated CEM destruction, an event dependent on $\mathrm{H}_{2} \mathrm{O}_{2}$ and myeloperoxidase (8), was consistently inhibited by these same $\mathrm{HOCl}$
TABLE II

Effect of HOCl Scavengers on Endothelial Cell and CEM Target Cell Lysis by Neutrophils

\begin{tabular}{lcr}
\hline & \multicolumn{2}{c}{ Percent control cytotoxicity" } \\
\cline { 2 - 3 } Scavenger* & Endothelial cell & CEM \\
\hline Isoleucine & $95 \pm 9$ & $23 \pm 3$ \\
Valine & $87 \pm 20$ & $15 \pm 9$ \\
Serine & $43 \pm 18$ & $9 \pm 4$ \\
\hline
\end{tabular}

* Each reaction mixture was preincubated 5 min with the L-amino acid at a final concentration of $20 \mathrm{mM}$.

$\$ 2 \times 10^{5}$ neutrophils were incubated with $2 \times 10^{4}$ endothelial cells with a final serum concentration of $0.25 \%$ and $10 \mathrm{ng} / \mathrm{ml}$ PMA. Mean control cytotoxicity was $38 \pm 9 \%(n=8)$.

$\$ 2 \times 10^{5}$ neutrophils were incubated with $2 \times 10^{4} \mathrm{CEM}$ with a final serum concentration of $0.25 \%$ and $10 \mathrm{ng} / \mathrm{ml}$ PMA $(n=3)$. In experiments with CEM targets control cytotoxicity was $50 \pm 8 \%(n=3)$.

" Results expressed as the mean \pm 1 SD of control cytotoxicity after a 6-h incubation.

scavengers (Table II). None of the amino acids tested inhibited neutrophil $\mathrm{O}_{2}{ }^{--}$or $\mathrm{H}_{2} \mathrm{O}_{2}$ generation. Thus, despite the ability of the amino acids to inhibit neutrophil-mediated destruction of the CEM targets, they fail to prevent endothelial cell cytolysis. It appears that $\mathrm{HOCl}$ does not play a strong role in neutrophilmediated endothelial cell damage.

\section{DISCUSSION}

We have previously demonstrated that human leukocytes are capable of destroying erythrocytes or CEM targets by oxygen-dependent mechanisms (6-9). The human vascular endothelium provides a particularly interesting target since intravascular activation of the neutrophil would expose the endothelium to a noxious environment. Possible in vivo activators of the neutrophil could include aggregated immunoglobulin, activated complement components, immune complexes, or bacterial peptides $(4,5)$. All of these agents can stimulate the neutrophil to discharge lysosomal enzymes and generate oxygen metabolites. In this study, we have used the soluble agent, PMA, as a model stimulus of leukocyte oxidative metabolism. Although PMA is not a physiological stimulus, it is capable of stimulating all aspects of oxidative metabolism normally associated with phagocytosis (27).

In this report, we have demonstrated that PMAstimulated neutrophils are capable of destroying suspensions or monolayers of cultured, human endothelial cells. Cytotoxicity was inhibited by catalase but not by superoxide dismutase. Thus, while $\mathrm{O}_{2}{ }^{\cdot-}$ itself does not appear cytotoxic, the product of its dismutation, $\mathrm{H}_{2} \mathrm{O}_{2}$, plays a key role in the cytotoxic event. The 
importance of $\mathrm{H}_{2} \mathrm{O}_{2}$ alone in endothelial cell destruction is reinforced by four additional observations. First, azide or cyanide, two potent heme-enzyme inhibitors, markedly stimulated neutrophil-mediated cytotoxicity. Either of these agents could block endothelial cell catalase or inhibit mitochondrial metabolism and increase the sensitivity of the cell to $\mathrm{H}_{2} \mathrm{O}_{2}$, but the addition of the inhibitors to the glucose oxidase system did not increase cytotoxicity. It appears that the stimulation of cytotoxicity in the neutrophil system reflects the increased availability of $\mathrm{H}_{2} \mathrm{O}_{2}$ secondary to the inhibition of neutrophil catalase and/or myeloperoxidase. Second, neutrophils isolated from patients with chronic granulomatous disease that are incapable of generating oxygen metabolites did not destroy endothelial cells in this system. Third, cells isolated from a patient with myeloperoxidase deficiency mediated significant endothelial cell cytotoxicity. Absence of this enzyme is associated with impaired bactericidal (28), fungicidal (29) and possibly tumoricidal (30) activity, but these cells were efficient in mediating endothelial cell cytotoxicity. Although only one patient was tested, it appears that the myeloperoxidasedeficient cells were even more cytotoxic than normal neutrophils at the low effector to target cell ratios. Myeloperoxidase deficient cells generate more $\mathrm{O}_{2}{ }^{--}$, $\mathrm{H}_{2} \mathrm{O}_{2}$ and possibly $\mathrm{OH} \cdot$ than normal neutrophils $(31,32)$ but appear to destroy endothelial cells by $\mathrm{H}_{2} \mathrm{O}_{2}$ alone. The utilization of these neutrophils clearly demonstrate the cytotoxic potential of cell-derived $\mathrm{H}_{2} \mathrm{O}_{2}$. Finally, the sensitivity of endothelial cells to $\mathrm{H}_{2} \mathrm{O}_{2}$ alone was demonstrated by using the glucose oxidase system. Less than $1 \mathrm{mU}$ of the enzyme system was capable of mediating significant endothelial cell destruction. Clark and Klebanoff have routinely used high doses of glucose oxidase with erythrocyte, leukocyte, and tumor cell targets without reporting cytotoxicity (33-35). In our experiments CEM were resistant to even higher doses of glucose oxidase than those used by Klebanoff and co-workers. ${ }^{2}$ Recently, Bass and Szejda reported that Trichinella larvae were highly sensitive to $\mathrm{H}_{2} \mathrm{O}_{2}$ based on the cytotoxic effect of $5 \mathrm{mU}$ of glucose oxidase in a 6-h assay (36). Apparently the endothelial cell is another example of a cell population with extreme sensitivity to $\mathrm{H}_{2} \mathrm{O}_{2}$.

Although both myeloperoxidase-deficient neutrophils and the glucose oxidase system could destroy endothelial cells by generating $\mathrm{H}_{2} \mathrm{O}_{2}$, this does not limit the normal neutrophil to the utilization of $\mathrm{H}_{2} \mathrm{O}_{2}$ as the sole cytotoxic agent. The addition of hemeenzyme inhibitors to normal neutrophils allowed us to demonstrate the sensitivity of the endothelial cell to $\mathrm{H}_{2} \mathrm{O}_{2}$ but masked the potential cytotoxicity of the

\footnotetext{
${ }^{2}$ Slivka, A., and S. Weiss. Manuscript submitted for publication.
}

myeloperoxidase system. Indeed, PMA-stimulated neutrophils can clearly destroy other target cells by generating $\mathrm{H}_{2} \mathrm{O}_{2}$ and releasing myeloperoxidase $(8,37)$. To investigate the sensitivity of the endothelial cells to the myeloperoxidase system, experiments were initially performed with the glucose-oxidase-myeloperoxidase model. Despite the ability of $\mathrm{H}_{2} \mathrm{O}_{2}$ alone to destroy endothelial cells, the addition of myeloperoxidase significantly stimulated cytolysis. The destructive role of myeloperoxidase-derived $\mathrm{HOCl}$ in the cytotoxic event was reinforced by the protective effect of the amino acids in the model system. Based on the sensitivity of the endothelial cells to the myeloperoxidase system and the ability of PMA-stimulated neutrophils to destroy other target cells by this mechanism, we were surprised by two observations. First, exogenous myeloperoxidase inhibited endothelial cell cytotoxicity mediated by both normal and myeloperoxidase-deficient neutrophils. Second, amino acids that were extremely effective in preventing glucose oxidase-myeloperoxidase-mediated cytotoxicity failed to strongly inhibit neutrophil-mediated destruction. The amino acids may have encountered difficulty in gaining access to the endothelial cell-neutrophil interface but this seems unlikely since these scavengers protected tumor cells from neutrophil-mediated cytotoxicity in an identical system. Serine alone significantly inhibited endothelial cell destruction by the neutrophils but the inability of the other scavengers to prevent cytolysis makes interpretation of its effect difficult. Although these results appear paradoxical, it is interesting to note that $(a)$ at low concentrations of glucose oxidase the addition of myeloperoxidase failed to stimulate endothelial cell destruction, and (b) these same doses of glucose oxidase and myeloperoxidase were more effective in destroying the tumor cells. It appears that the $\mathrm{H}_{2} \mathrm{O}_{2}$-resistant tumor cell is more sensitive to $\mathrm{HOCl}$ than the endothelial cell. Thus, despite being exposed to neutrophil-derived $\mathrm{H}_{2} \mathrm{O}_{2}$ and myeloperoxidase, the endothelial cell is primarily sensitive to $\mathrm{H}_{2} \mathrm{O}_{2}$ and not myeloperoxidase-derived products. Alternatively, we cannot rule out the possibility that the less reactive species, $\mathrm{H}_{2} \mathrm{O}_{2}$, is able to reach the endothelial cell at a higher concentration than the more reactive $\mathrm{HOCl}$.

Sacks et al. (38) also studied the effect of neutrophilderived oxygen metabolites in endothelial cell injury. They demonstrated that human neutrophils stimulated with C5a were capable of destroying monolayers of umbilical vein endothelial cells. In their report, neutrophils mediated $5-10 \%$ damage as assessed by ${ }^{51} \mathrm{Cr}$ release and 20-30\% damage by viability staining after a 90-min incubation. Endothelial cell destruction was partially inhibited by catalase while superoxide dismutase had no effect but, the addition of both enzymes effectively inhibited ${ }^{51} \mathrm{Cr}$ release. In addition, neutro- 
phils isolated from a patient with chronic granulomatosus disease were capable of mediating a cytotoxic response $50 \%$ as effective as that obtained with control neutrophils. The authors concluded that C5a stimulated neutrophils destroyed endothelial cells by a mechanism dependent on an uncharacterized oxygen radical. Although their conclusions differ from our own, $\mathrm{H}_{2} \mathrm{O}_{2}$ might be the mediator of cytotoxicity in the C5a system. The enhanced inhibition of cytotoxicity seen with catalase and superoxide dismutase could be secondary to the prevention of catalase inactivation by $\mathrm{O}_{2}{ }^{--}$(39), but we cannot rule out the possibility that different cytotoxic mechanisms may be operative with different stimuli. We attempted to use opsonized zymosan as another stimulus of leukocyte metabolism but it failed to mediate cytotoxicity. The addition of unopsonized zymosan to PMA-stimulated neutrophils completely inhibited endothelial cell cytotoxicity, probably by providing an additional oxidizeable substrate. PMA has the advantage of being an extremely potent stimulus that does not introduce large quantities of competing substrate at the effector-target cell interface.

Nathan et al. (40) also used PMA as a pharmacologic trigger with a murine macrophage model system. They reported that PMA-stimulated murine macrophages could destroy a variety of human and murine cell lines by a mechanism dependent on $\mathrm{H}_{2} \mathrm{O}_{2}$ alone. These results contrast with our observations on the mechanisms operable in neutrophil-mediated destruction of erythrocytes and tumor cells (6-9). In addition, Clark and Klebanoff recently demonstrated the ability of neutrophil-derived $\mathrm{H}_{2} \mathrm{O}_{2}$ to initiate a platelet release reaction (41). In contrast with our studies, the myeloperoxidase-deficient neutrophils did not mediate the release reaction and the effect of $\mathrm{H}_{2} \mathrm{O}_{2}$ was only seen in the presence of heme enzyme inhibitors. Thus far, the endothelial cell is the only target that we have identified as sensitive to leukocyte-derived $\mathrm{H}_{2} \mathrm{O}_{2}$. Apparently, the selection of the effector cell, target cell and stimulus all play an important role in the determination of the mechanism of cytotoxicity.

Although caution should be exercised in extending the observations made with cultured venous endothelial cells of fetal origin, it is interesting to speculate on the possible sensitivity to the adult vascular endothelium. Wall et al. (42) have recently suggested that homocysteine-induced atherosclerosis might be due to $\mathrm{H}_{2} \mathrm{O}_{2}$ generated from the autooxidizing drug. In addition, it has long been appreciated that the pulmonary endothelium is especially sensitive to hyperoxic damage (43). Indeed, pulmonary endothelial cells are the first cells damaged despite the exposure of the alveolar epithelium to similar $\mathrm{O}_{2}$ tensions (43). It appears that the endothelium may be a particular risk to oxygen-dependent damage regardless of the oxidant source. Studies to determine the susceptibility of other vascular tissues to $\mathrm{H}_{2} \mathrm{O}_{2}$ and the biochemical nature of the endothelium's sensitivity to this oxidant are underway.

\section{ACKNOWLEDGMENTS}

We are indebted to Dr. Richard K. Root and Dr. John Ryan (Yale University School of Medicine) for providing us with laboratory space to perform the experiments with the myeloperoxidase-deficient blood. We also wish to thank the obstetrics staff of Women's Hospital and Saint Joseph's Hospital (Ann Arbor) for providing us with umbilical cords.

This work was supported by the Michigan Heart Association and grant R01-AI-16524-01 from the National Institutes of Health.

\section{REFERENCES}

1. Ross, R., and J. A. Glomset. 1976. The pathogenesis of atherosclerosis, Part 1. N. Engl. J. Med. 295: 369-377.

2. Ross, R., and J. A. Glomset. 1976. The pathogenesis of atherosclerosis, Part 2. N. Engl. J. Med. 295: 420-425.

3. Harker, L. A., and R. Ross. 1979. Pathogenesis of arterial vascular disease. Semin. Thromb. and Hemostasis. 5: 274-292.

4. Babior, B. M. 1978. Oxygen-dependent microbial killing by phagocytes. N. Engl. J. Med. 298: 659-668.

5. Klebanoff, S. J. 1980. Oxygen metabolism and the toxic properties of phagocytes. Ann. Intern. Med. 93: 480-489.

6. Weiss, S. J., A. F. LoBuglio, and H. B. Kessler. 1980. Oxidative mechanisms of monocyte-mediated cytotoxicity. Proc. Natl. Acad. Sci. U. S. A. 77: 584-587.

7. Weiss, S. J., and A. F. LoBuglio. 1980. An oxygen-dependent mechanism of neutrophil-mediated cytotoxicity. Blood. 55: 1020-1024.

8. Slivka, A., A. F. LoBuglio, and S. J. Weiss. 1980. A potential role for hypochlorous acid in granulocyte-mediated tumor cell cytotoxicity. Blood. 55: 347-350.

9. Weiss, S. J. 1980. The role of superoxide in the destruction of erythrocyte targets by human neutrophils. J. Biol. Chem. 255: 9912-9917.

10. Weiss, S. J., P. K. Rustagi, and A. F. LoBuglio. 1978. Human granulocyte generation of the hydroxyl radical. J. Exp. Med. 147: 316-323.

11. Gimbrone, M. A. 1976. Culture of vascular endothelium In Progress in Hemostasis and Thrombosis. T. H. Spaet, editor. Grune \& Stratton, New York. 3: 1-28.

12. Weibel, E. R., and G. E. Palade. 1964. New cytoplasmic components in arterial endothelia. J. Cell Biol. 23: 101-112.

13. Jaffe, E. A., L. W. Hoyer, and R. L. Nachman. 1973. Synthesis of antihemophilic factor antigen by cultured human endothelial cells. J. Clin. Invest. 52: 2757-2769.

14. Shaw, G. M., P. C. Levy, and A. F. LoBuglio. 1978. Human monocyte cytotoxicity to tumor cells. J. Immunol. 121: 573-578.

15. Harrison, J. E., S. Pabalan, and J. Schultz. 1977. The subunit structure of crystalline canine myeloperoxidase. Biochim. Biophys. Acta. 493: 247-259.

16. Worthington Enzyme Manual. 1972. Worthington Biochemical Corp., Freehold, N. J.

17. Thurman, R. G., H. G. Ley, and R. Scholz. 1972. Hepatic microsomal ethanol oxidation. Eur. J. Biochem. 25: 420-430.

18. Homan-Muller, J. W. T., R. S. Weening, and D. Roos. 1975. Production of hydrogen peroxide by phagocytizing human granulocytes. J. Lab. Clin. Med. 85: 198-207. 
19. White, J. G., and R. E. Estensen. 1974. Selective labilization of specific granules in polymorphonuclear leukocytes by phorbol myristate acetate. Am. J. Pathol. 75: 45-54.

20. Wright, O. G., D. A. Bralove, and J. I. Gallin. 1977. The differential mobilization of human neutrophil granules. Am. J. Pathol. 87: 273-281.

21. Hill, H. A. 1979. The chemistry of dioxygen and its reduction products. In Oxygen Free Radicals and Tissue Damage. Ciba Foundation Symposium. Excerpta Medica, New York. 5-12.

22. Agner, K. 1972. Biological effects of hypochlorous acid formed by "MPO" peroxidation in the presence of chloride ions. In Structure and Function of OxidationReduction Enzyme. A. Akeson and A. Ehrenberg, editors. 329-335.

23. Harrison, J. F., and J. Schultz. 1976. Studies on the chlorinating activity of myeloperoxidase. J. Biol. Chem. 251: 1371-1374.

24. Zgliczynski, J. M., R. J. Selvaraj, B. B. Paul, T. Stelmaszynska, P. K. Poskitt, and A. J. Sbarra. 1977. Chlorination by the myeloperoxidase $-\mathrm{H}_{2} \mathrm{O}_{2}-\mathrm{Cl}^{-}$antimicrobial system at acid and neutral pH. Proc. Soc. Exp. Biol. Med. 154: 418-422.

25. Sbarra, A. J., R. J. Selvaraj, B. B. Paul, P. K. Poskitt, G. W. Mitchell, F. Louis, and M. A. Asbell. 1977. Granulocyte biochemistry and a hydrogen peroxide-dependent antimicrobial system. In The Granulocyte: Function and Clinical utilization. T. J. Greenwalt and G. A. Jamieson, editors. Alan Liss, Inc., New York. 29-48.

26. Thomas, E. L. 1979. Myeloperoxidase, hydrogen peroxide, chloride antimicrobial system: nitrogen-chlorine derivatives of bacterial components in bactericidal action against Eschericia coli. Infect. Immun. 23: 522-531.

27. DeChatelet, L. R., P. S. Shirley, and R. B. Johnson. 1976. Effect of phorbol myristate acetate on the oxidative metabolism of human polymorphonuclear leukocytes. Blood. 47: 545-554.

28. Klebanoff, S. J., and C. B. Hamon. 1972. Role of myeloperoxidase-mediated antimicrobial systems in intact leukocytes. J. Retic. Soc. 12: 170-196.

29. Lehrer, R. I., and M. J. Cline. 1969. Leukocyte myeloperoxidase deficiency and disseminated candidiasis: the role of myeloperoxidase in resistance to Candida infection. J. Clin. Invest. 48: 1478-1488.

30. Clark, R. A., and S. J. Klebanoff. 1979. Role of myeloperoxidase- $\mathrm{H}_{2} \mathrm{O}_{2}$-halide system in Concanavalin A-in- duced tumor cell killing by human neutrophils. $J$. Immunol. 122: 2605-2610.

31. Rosen, H., and S. J. Klebanoff. 1976. Chemiluminescence and superoxide production by myeloperoxidase-deficient leukocytes. J. Clin. Invest. 58: 50-60.

32. Rosen, H., and S. J. Klebanoff. 1979. Hydroxyl radical generation by polymorphonuclear leukocytes measured by electron spin resonance spectroscopy. J. Clin. Invest. 64: 1725-1729.

33. Klebanoff, S. J., and R. A. Clark. 1975. Hemolysis and iodination of erythrocyte components by a myeloperoxidase-mediated system. Blood. 45: 699-707.

34. Clark, R. A., and S. J. Klebanoff. 1975. Neutrophil-mediated tumor cell cytotoxicity: role of the peroxidase system. J. Exp. Med. 141: 1442-1447.

35. Clark, R. A., and S. J. Klebanoff. 1977. Myeloperoxidase$\mathrm{H}_{2} \mathrm{O}_{2}$-halide system: cytotoxic effects on human blood leukocytes. Blood. 50: 65-70.

36. Bass, D. A., and P. Szejda. 1979. Mechanisms of killing of newborn larvae of Trichinella spiralis by neutrophils and eosinophils. J. Clin. Invest. 64: 1558-1564.

37. Clark, R. A. 1979. Toxic effects of myeloperoxidase and $\mathrm{H}_{2} \mathrm{O}_{2}$ secreted by neutrophils exposed to a soluble stimulus. Clin. Res. 27: 209A. (Abstr.).

38. Sachs, T., C. F. Moldow, P. R. Craddock, T. K. Bowers, and H. S. Jacob. 1978. Oxygen radicals mediate endothelial cell damage by complement-stimulated granulocytes. J. Clin. Invest. 61: 1161-1167.

39. Michelson, A. M. 1977. Chemical production of superoxide anions by reaction between riboflavin, oxygen and reduced nicotinamide adenine dinucleotide. Specificity of tests for $\mathrm{O}_{2}^{-{ }^{-}}$. In Superoxide and Superoxide Dismutases. A. M. Michelson, J. M. McCord, and I. Fridovich, editors. Academic Press, Inc., New York. 87-106.

40. Nathan, C. F., S. C. Silverstein, L. H. Brukner, and Z. A. Cohn. 1979. Extracellular cytolysis by activated macrophages and granulocytes. II. Hydrogen peroxide as a mediator of cytotoxicity. J. Exp. Med. 149: 100-113.

41. Clark, R. A., and S. J. Klebanoff. 1980. Neutrophil-platelet interaction mediated by myeloperoxidase and hydrogen peroxide. J. Immunol. 124: 399-405.

42. Wall, R. T., J. H. Harlan, L. A. Harker, and G. E. Striker. 1978. Mechanisms of homocysteine-induced endothelial injury. Clin. Res. 26: 359A. (Abstr.).

43. Lee, F., and D. Massaro. 1980. Oxygen toxicity. Am. J. Med. 69: $117-126$ 